\title{
THE CALLOVIAN UNCONFORMITY AND THE OPHIOLITE OBDUCTION ONTO THE PELAGONIAN CARBONATE PLATFORM OF THE INTERNAL HELLENIDES
}

\author{
Scherreiks R. ${ }^{1}$, Meléndez G. ${ }^{2}$, Bouldagher-Fadel M. ${ }^{3}$, Fermeli G. ${ }^{4}$ and \\ Bosence D. ${ }^{5}$ \\ ${ }^{1}$ Bayerische Staaatssammlung, Department of Geology, University of Munich, Luisenstr. 33, \\ 80333 Munich, Germany, r.scherreiks@hotlinemail.com \\ ${ }^{2}$ Departamento de Geologia (Paleontologia), Universidad de Zaragoza, 50009 Saragossa, Spain, \\ gmelende@unizar.es \\ ${ }^{3}$ Earth Sciences, University College London, Gower Street, London WC1E6BT, UK, \\ m.fadel@ucl.ac.uk \\ ${ }^{4}$ Department of Historical Geology and Paleontology, University of Athens, Panepistimioupolis, \\ Zographou, 15784 Athens, Greece, gfermeli@geol.uoa.gr \\ ${ }^{5}$ Department of Earth Sciences, Royal Holloway University of London, Egham TW20 0EX, UK, \\ d.bosence@es.rhul.ac.uk
}

\begin{abstract}
The carbonate-platform-complex and the oceanic formations of the central Pelagonian zone of the Hellenides evolved in response to a sequence of plate-tectonic episodes of ocean spreading, plate convergence and ophiolite obduction. The biostratigraphies of the carbonate platform and the oceanic successions, show that the Triassic-Early Jurassic platform was coeval with an ocean where pillow basalts and radiolarian cherts were being deposited. After convergence began during late EarlyJurassic - Middle Jurassic time, the oceanic leading edge of the Pelagonian plate was subducted beneath the leading edge of the oceanic, overriding plate. The platform subsided while a supra-subduction, volcanic-island-arc evolved. Biostratigraphic and geochemical evidence shows that the platform and the oceanic floor, temporarily became subaerially exposed during Callovian time. This "Callovian event" is suggested to have taken place as oceanic lithosphere first made compressional, tectonic contact with the carbonate platform, initiating a basal detachment fault, along which the platform was thrust upwards. The central Pelagonian zone became an extensive land area that was supplied with laterite from an ophiolite highland. A similar emergence of Vardar ophiolite most likely took place in the Guevgueli area. The Callovian emergence shows that the initial ophiolite obduction onto the platform took place about 25 million years before the final emplacement of the ophiolite during Valanginian time.

Keywords: Bio-facies, litho-facies, Foraminifera, Radiolarite, Plate convergence, Laterite, Callovian event, Ophiolite obduction.
\end{abstract}




\section{Introduction}

The Pelagonian carbonate complex of the Hellenides is covered by sporadically-distributed remnants of an ophiolite sheet (Fig.1) which was obducted onto the Pelagonian micro-plate during Valanginian time. The convergence of the oceanic (ophiolite) plate with the Pelagonian plate has been postulated $t$ o have begun around late Early-Jurassic time as a result of intra-oceanic subduction (Bèbien et al., 19 80, and Spray and Roddick 1980) (compare Scherreiks et al., 2014). However, about 25 ma prior to the final emplacement of the ophiolite during Valanginian time, both the platform and the ophiolite became subaerially exposed during late Bathonian to early Oxfordian time. This major tectonostratigraphic event of Callovian time is the main theme of this contribution which is founded on the interpretations and re-evaluations of bio- and litho-stratigraphic- and geochemical-analyses, and field investigations (Scherreiks et al., 2014). In a regional context, this palaeogeographic conception generally corresponds to the palaeogeographic evolution that has been forwarded for the Vardar Ocean Unit of the Balkan (Robertson et al., 2013; Kukoc et al., 2015). Basic previous research has been done by Aubouin and Guernet (1964), Katsikatsos (1976), Machairas (1978), Katsikatsos et al. (1980, 1981, 1984) and Scherreiks (2000).

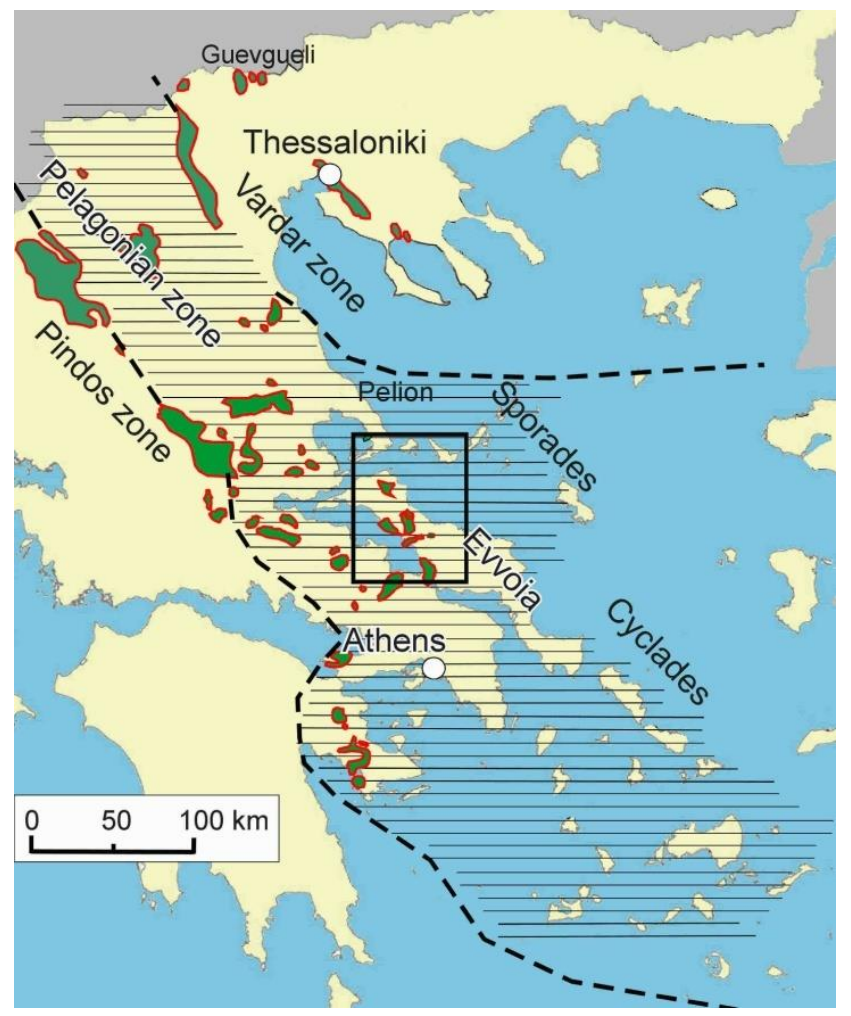

Figure 1 - The study area in the Pelagonian zone of the Internal Hellenides (Ophiolite remnants shown in green).

\section{Stratigraphy, litho-facies and palaeontology (cf. Fig. 2)}

\subsection{The Late Triassic-Early Jurassic, peritidal carbonate-platform and the coeval oceanic realm prior to plate convergence}

A peritidal carbonate platform evolved between the Late Triassic and the Sinemurian (Fig.2). The typical cyclical peritidal facies (Bosence et al., 2009) are characterised by pervasively dolomitized microbial mats (stromatolites), pisolite rudstone with meniscus cements, intraclast floatstone, and 
intertidal mudstones. The bio-stratigraphy verifies Late Triassic through Sinemurian age of the peritidal platform (Table 1), which evolved concurrently with an oceanic realm, characterised by (MORB) pillow basalt and (below CCD) radiolarites of Late Triassic age (Table 2a).

Table 1 - Rhaetian - Sinemurian foraminifera, determined in co-operation with BoudagherFadel (2008).

\begin{tabular}{|c|}
\hline Grillina sp. \\
Auloconus permodiscoides \\
Aulotortus friedly \\
Siphovalvulina gibraltarensis \\
Siphonina gibraltarensis \\
\hline
\end{tabular}

Table 2 - Radiolarians cherts above pillow basalts, determined in co-operation with P. $O$. Baumgartner (Baumgartner et al. 1995).

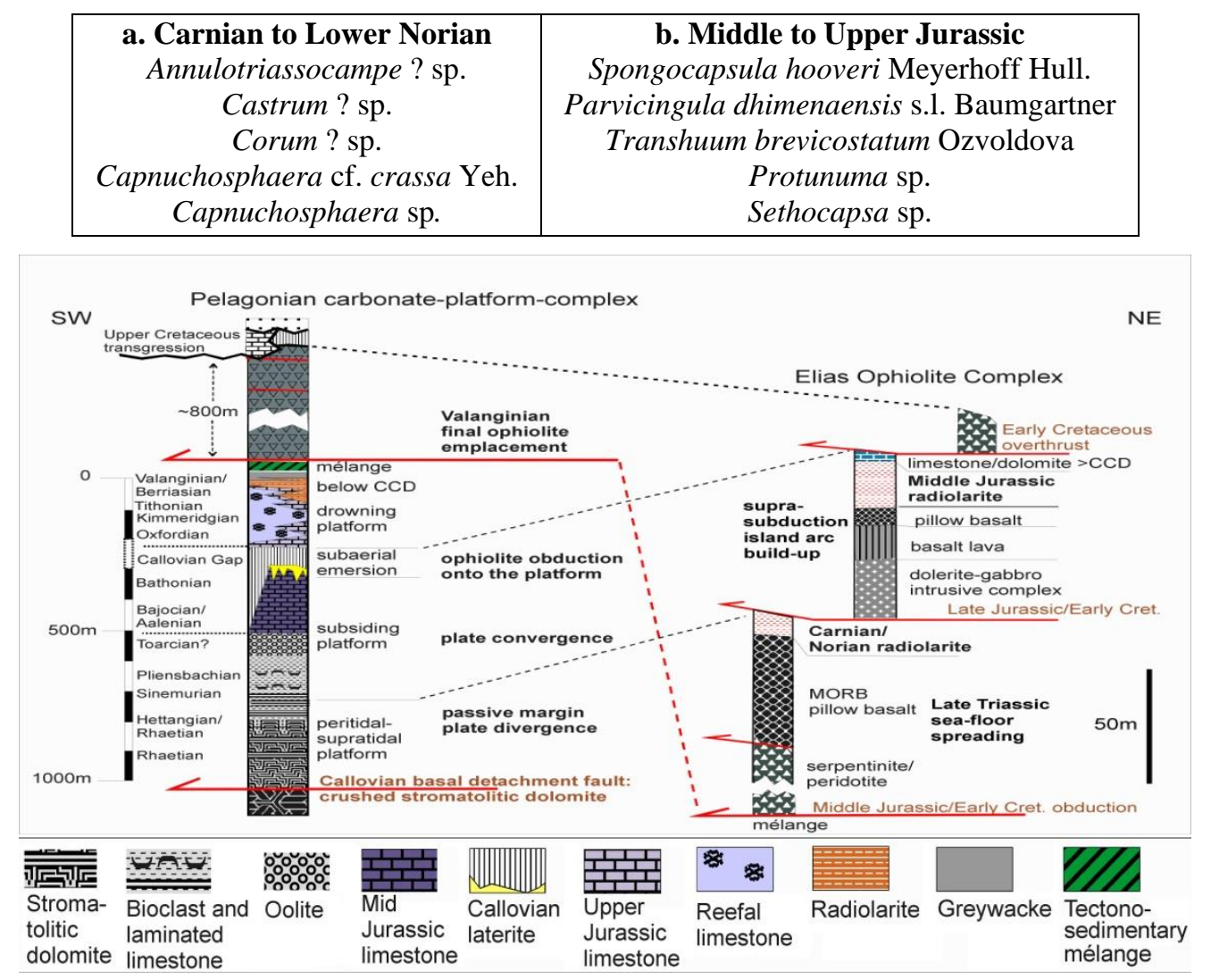

Figure 2 - Composite stratigraphies of the platform and ophiolite complexes of northern Evvoia.

\subsection{Pliensbachian-Bathonian plate convergence, platform subsidence and ocean- floor uplift}

From the Sinemurian onwards the platform subsided continuously until Bathonian time, which is indicated by a succession of deepwater carbonates: thin-shelled (filament) wackestone, siliceous spiculite - radiolarian wackestone, and calcisphere-spiculite-radiolarian packstone. The biostratigraphy Table 3a-c) verifies Pliensbachian through Bathonian age. 
The Middle Jurassic subsidence of the platform is attributed to the convergence of the eastern ophiolite sheet over the oceanic leading edge of the Pelagonian micro-plate (Fig. 3a). This is documented by Middle Jurassic radiolarians which have been found in the melange below the overriding ophiolite sheet (Danelian and Robertson, 2001; Scherreiks et al., 2014), showing that the ophiolite advanced over an ocean floor during Middle Jurassic time (Fig.3a). Coeval Middle Jurassic radiolarites also occur, in sedimentary contact, with basalts of the eastern Vardar ophiolite (Guevgueli Ophiolite Complex of Macedonia: Kukoc et al., 2015).

The upper part of the oceanic stratigraphic-column (Fig. 2) consists of gabbro, flood- basalt, and pillow basalt covered by radiolarite of late Middle Jurassic age (Table 2b). Nodular-chert carbonates occur toward the top (Fig 2 Elias complex), indicating that the ocean floor had been uplifted above the concurrent CCD during late Middle Jurassic time (Fig. 3b). Previously carried out geochemical analyses (Scherreiks et al., 2014) have shown that the gabbros and basalts conform to the calcalkaline magmatic series which is related to volcanic island-arc realms. This has also been confirmed in tectonic discrimination diagrams (Scherreiks et al., 2014). A supra-subduction, volcanic, island arc is thought to have evolved during the Middle Jurassic and is represented by the Elias Complex (Fig. 2 and Fig. 3a), which became uplifted during the convergence of the two plates.

Table 3 - Pliensbachian-Oxfordian bio-stratigraphy, determined in co-operation with Boudagher-Fadel (2008).

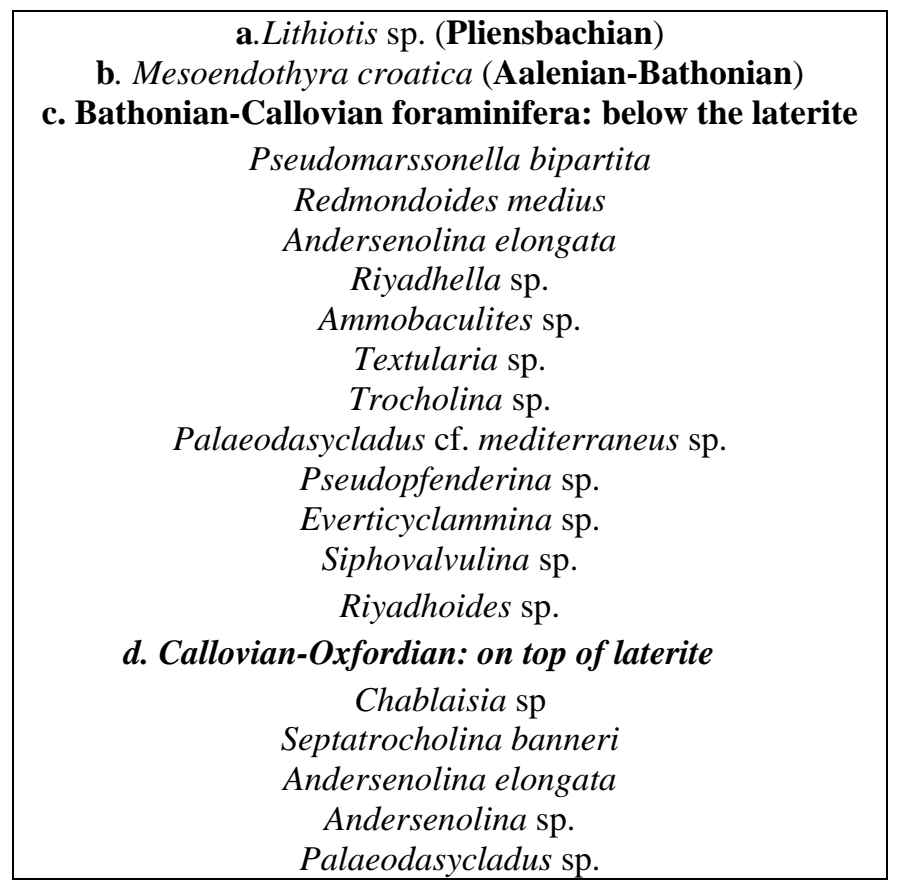

\subsection{The Callovian event: ophiolite obduction and sub-aerial exposure of the ophiolite and the platform]}

Unconformities of Callovian age are widespread in the Mediterranean region (Meléndez, 1989 and Meléndez and Martínez, 2007). In the central Pelagonian zone, laterite occurs in discontinuous karst vugs and caverns and as lateritic crusts on top of shallow marine limestones (Fig.2). Previous analyses have shown that these laterites are bauxites (Guernet and Robert, 1973). The foraminiferal assemblage of the limestones subjacent to the laterite (Table 3c) contains Pseudomarssonella bipartita Redmond (Bou Dagher-Fadel, 2008; Scherreiks et al., 2014) of Late Bathonian age, verifying that the event of emersion, during which time the laterites were deposited, must have occurred during or after the late Bathonian. The laterite is an aluminium-enriched bauxite (>71\% 
A12O3) with high trace element contents of $\mathrm{Co}, \mathrm{Cr}$, Ni and $\mathrm{V}$, which have been verified in the 10500 PPM range in numerous laterite occurrences of the study area (Scherreiks et al., 2014). The high aluminium content and the trace element contents of $\mathrm{Co}, \mathrm{Cr}, \mathrm{Ni}$ and $\mathrm{V}$, fingerprint basalt as having been the most probable source of the lateritic deposits, definitely indicating that oceanic crust had been subaerially exposed during later Bathonian time and had undergone lateritic weathering. Ophiolite-derived laterite apparently had been transported and deposited onto the contemporaneously exposed, karstic platform surface, forming lateritic regolith that infiltrated pervasive fractures, karstic vugs and karst collapse breccias.

The limestones cropping out immediately above the laterites are shallow marine, peloid-bioclast grainstones and packstones. They contain a Callovian-Oxfordian foraminiferal assemblage (Table 3d) in which the presence of Chablaisia shows them to be not younger than early Oxfordian (Bou Dagher-Fadel, 2008; Scherreiks et al., 2014). They document an early Oxfordian transgression over the laterites. From the above, the period of emergence during which the platform and ophiolite had been exposed occurred between late Bathonian and before the transgression of the early Oxfordian shallow marine carbonates.

The emersions of the ophiolite and platform were coeval with the carbonate deposition on top of late Mid Jurassic radiolarites of the rising oceanic island arc (Fig. 2, Table 2b, and Fig. 3b-c).

\subsection{Oxfordian-Valanginian: platform drowning prior to the final ophiolite emplacement}

Shallow marine carbonates devoid of ophiolite detritus appear on top of the Callovian laterite (Fig. 2). The temporarily exposed ophiolite of Late Bathonian to early Oxfordian time apparently became submerged during early Oxfordian time. Reef limestones occur (Fig. 2), which are characterised by Cladocoropsis mirabilis Felix (Scherreiks et al., 2014), of the middle Oxfordian Cladocoropsis Zone (Turnsek et al., 1981). The upper stratigraphic range of the Cladocoropsis zone, in the study area, most probably extends into the Berriasian, because $C$. mirabilis occurs together with Zergabriella embergeri, which has a stratigraphic range from Tithonian to Valanginian (Granier, 1989). Cladocoropsis and Zergabriella were found together (Scherreiks et al., 2010) in turbidite that interfingers with radiolarian cherts and shales that range in age from Berriasian to Valanginian (Baumgartner and Bernoulli, 1976).

Lenses of fine-grained turbiditic, siliciclastic sandstones interdigitate with cherts and shales in the upper part of the drowned platform radiolarite sequence (Fig. 2). Inasmuch as this greywacke succeeds Berriasian-Valanginian radiolarite, it is most probably of later Valanginian age. The ophiolite nappe together with sub-ophiolite mélange advanced over and scraped up greywacke and radiolarite and terminated platform sedimentation in the vicinity of the study area during Valanginian time. However, it is noteworthy that the actual ophiolite obduction onto the platform began 25 ma earlier during late Bathonian time (see above).

\section{Discussion}

Intra-oceanic subduction and convergence initially led to the obduction of the overriding ophiolite sheet onto the oceanic leading edge of the Pelagonian micro-plate (Fig. 3a). This was a diachronic process that began around late Early Jurassic to early Mid Jurassic time and finally led to the emplacement of the ophiolite on top of the Pelagonian carbonate platform during Valanginian time. The evidence for this time-schedule stems from the dating of radiolarians from the mélange beneath the ophiolite and the radiolarians from the drowned carbonate platform. The mélange contains mid oceanic pillow basalt with Mid Jurassic radiolarite, indicating that the ophiolite sheet must have been advancing over oceanic crust during Mid Jurassic time, whereas the age of the youngest drowned-platform radiolarians is Valanginian. But when did the ophiolite begin its obduction over the carbonate platform? 


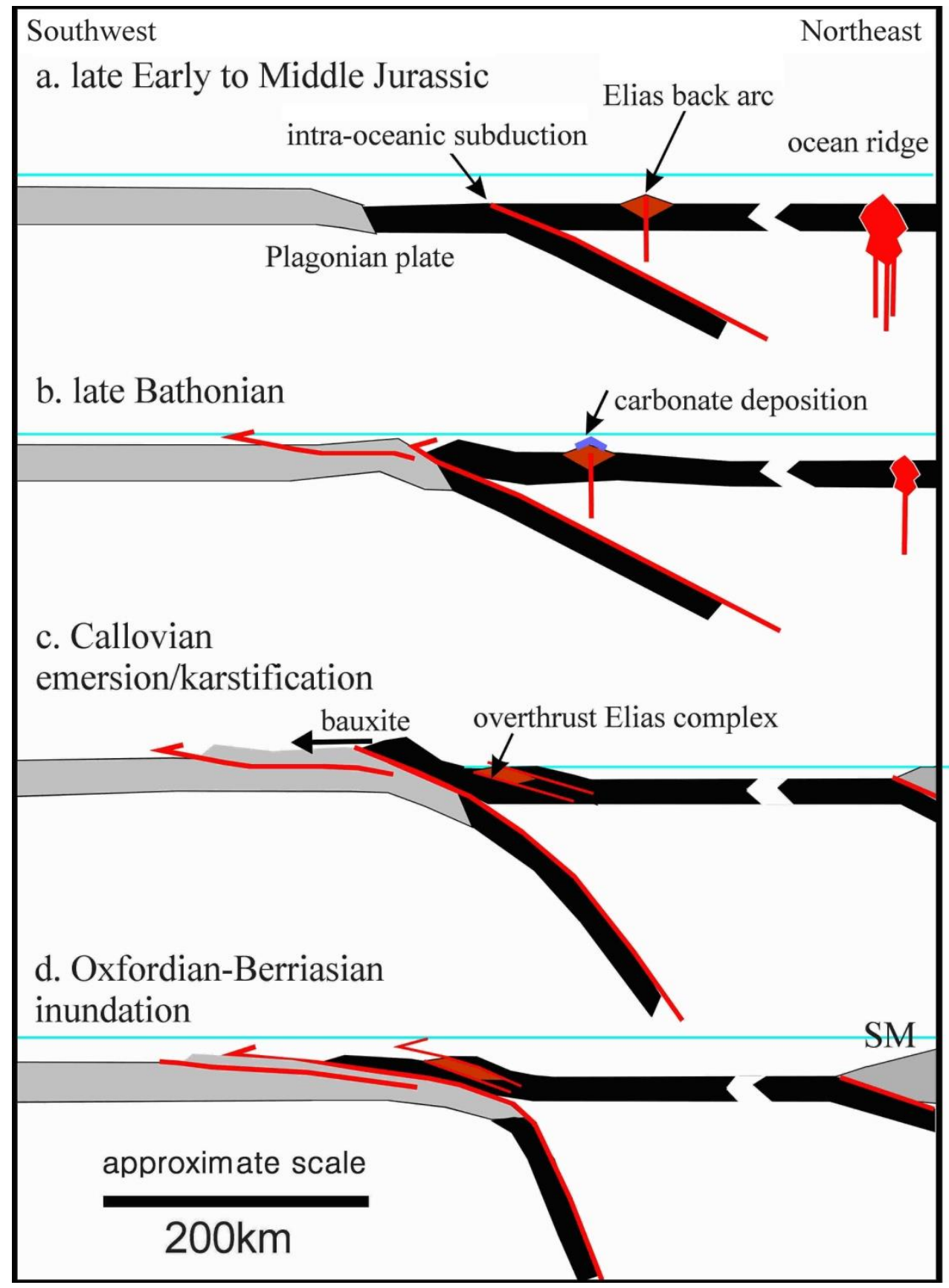

Fig. 3 - Schematic plate-tectonic episodes of obduction and emersion of the ophiolite and the platform during Callovian time (SM: Serbo-Macedonian Massif). a) Intra-oceanic subduction initiates back-arc volcanism. b) Ophiolite obduction leads to thrust faulting in the platform and uplift of back-arc. c) Platform is thrust upward and the overriding ophiolite becomes emergent, resulting in karstification and laterite deposition. d) Platform loading and continued obduction initiates the Oxfordian-Berriasian inundation. 
The earliest evidence that the ocean floor began to rise above the CCD is found in the stratigraphy of the Elias complex which shows a succession of late Middle Jurassic pillow basalt and radiolarite covered by pelagic limestone (Fig. 2 and Fig. 3b). The stratigraphy of the carbonate platform shows that as the ophiolite rose during the late Middle Jurassic, the platform also rose during late Bathonian time. The platform then became emergent during Callovian time, was karstified, and was covered by laterite having an ophiolitic geochemical signature. Thus, it is apparent that the ophiolite must also have been emergent. In spite of the evidence, it appears illogical that a plate that is being overthrust would be uplifted, it should have subsided. This paradox is resolved by postulating that the platform was thrust upwards as it made contact with the advancing ophiolite (Fig. 3b-c). Evidence for a basal detachment fault is given by the crushed Triassic carbonates at the base of the carbonate platform (Fig. 2). As the ophiolite initially overrode the Pelagonian plate it was uplifted (Fig. 3c) and was weathered before it was inundated together with the carbonate platform during Oxfordian time (Fig. 3d).

\section{Conclusions}

The ophiolite sheet advanced over Mid Jurassic oceanic lithosphere toward the Pelagonian platform while a supra-subduction volcanic arc (Elias complex Fig. 2) evolved within the overriding plate (Fig. 3b). The actual tectonic contact of oceanic lithosphere with the Pelagonian platform began during late Bathonian time and is thought to have initiated the detachment fault within the platform (Fig. 2). The platform was thereby thrust upwards while the front of the ophiolite sheet and the platform became emergent (Fig. 3b-c). As a result, a karstic land area and an ophiolite highland, that underwent lateritic weathering, existed in the central Pelagonian zone during Callovian time. Ophiolite subaerial weathering has also been reported from the Guevgueli Complex (Robertson et al., 2013; Kukuc et al., 2015) and most likely correlates with the Callovian event of the central Pelagonian area. The Late Jurassic conglomerates of the eastern Vardar Unit (Kukoc et al., 2015) are suggested here to have been derived from the eastern side of an uplifted back-arc complex, of which the Elias Complex is a small preserved more westerly situated remnant.

Renewed subsidence of both the ophiolite and the platform during the Late Jurassic is suggested to have been caused by gravitational pull and rollback of the subducted leading oceanic edge of the $\mathrm{P}$ elagonian plate (Fig. 3c-d). Subsidiary thrust faults formed within the ophiolite as it advanced during the Late Jurassic (Fig. 2 and Fig 3c-d). The ophiolite sheet continued to advance in the study area until Valanginian time. The basal detachment fault beneath the platform may have been reactivated after Valanginian and post- Cretaceous time, as the Serbo-Macedonian massif advanced and closed the adjacent eastern Vardar ocean (Fig. 3c-d) (Scherreiks et al., 2014). The closure of the Vardar ocean and the collision between the Serbo-Macedonian massif and the Pelagonian plate most probably caused the Upper Cretaceous erosional unconformity (Fig. 2).

\section{Acknowledgements}

The institutes affiliated with the authors are thanked for providing support and facilities throughout many years of research: Department of Earth Sciences, UCL, London, Office of the Vice-Provost ( Research); Departamento de Geología (Paleontología), Universidad de Zaragoza; Department of H istorical Geology and Paleontology, University of Athens; Department of Earth Sciences, Royal H olloway University of London; Bayerische Staatssammlung für Palaeontologie und Geologie, Mun ich; for preparatory work, personal thanks are given, Elisabeth von Berg. This paper was partly sup ported by the research projects: Research project No. CGL 2011-23947 (MICINN) from the Spanis h Ministry of Science and Innovation; EU Project No. 510508-LLP-1-2010-GR-COMENIUS-CM P: GEOschools (EACEALLP); the international ERASMUS interchange program (Univ. Athens a nd Zaragoza); the Regional Government of Aragón (Group DGA: E-17). Prof. Peter O. Baumgartn er and his dissertation students Yanik Gingins and Olivier Schauner, Geology Department, Univers 
ity of Lausanne, are gratefully acknowledged for co-operation during fieldwork which led to radiol arian determinations and to basalt analyses.

\section{References}

Aubouin, J. and Guernet, Cl., 1964. Sur la stratigraphie et la téctonique de l'Eubée moyenne (Gréce), Bull. Soc. Géol. Fr., 5(1963), 821-827.

Baumgartner, P.O. and Bernoulli, D., 1976. Stratigraphy and radiolarian fauna in a Late Jurassicearly cretaceous section near Achladi, Evvoia, eastern Greece, Eclogae Geol. Helv., 69, 601626.

Baumgartner, P.O., Bartolini, A., Carter, E.S., Conti, M., Cortese, G., Danelian, T., De Wever, P., Dumitrica, P., Dumitrica-Jud, R., Gorican, S., Guex, J., Hull, D.M., Kito, N., Marcucci, M., Matsuoka, A., Murchey, B., O’Dogherty, L., Savary, J., Vishnevskaya, V., Widz, D. and Yao, A., 1995. Middle Jurassic to early cretaceous radiolarian biochronology of Tethys based on unitary associations. In: Baumgartner, P.O. et al., eds., Middle Jurassic to lower cretaceous Radiolaria of Tethys: occurrences, systematics, biochronology, Mém. Géol., (Lausanne), 23, 1013-1048.

Bèbien, J., Ohnenstetter, D., Ohnenstetter, M. and Vergély, P., 1980. Diversity of the Greek ophiol ites: birth of the oceanic basins in transcurrent systems, Ofioliti, 2, 129-197.

Bosence, D., Procter, E., Aurell, M., Atef Bel, K., Boudagher-Fadel, M., Casaglia, F., Cirilli, S., Mehdie, M., Nieto, L., Rey, J., Scherreiks, R., Soussi, M. and Waltham, D., 2009. A dominant tectonic signal in high-frequency, peritidal carbonate cycles? A regional analysis of Liassic platforms from western Tethys, J. Sed. Res., 79(5-6), 389-415.

Boudagher-Fadel, MK., 2008. The Mesozoic larger benthic foraminifera: the Jurassic. In: Boudagher-Fadel, M.K., ed., Evolution and geological significance of larger benthic foraminifera, Wignall PB (series ed) Dev Palaeontol Strat 21, Elsevier, Amsterdam.

Danelian, T. and Robertson, A.H.F., 2001. Neotethyan evolution of eastern Greece Pagondas Mélange, Evia island inferred from radiolarian biostratigraphy and the geochemistry of associated extrusive rocks, Geol. Mag., 138, 345-363.

Granier, B., 1989. Zergabriella, un nouveau genre d'algue Dasycladale du Portlandien-Valanginien; Zergabriella, a new genus of Dasyclad algae from the Portlandian-Valanginian times, Rev. Micropaléontol., 32, 126-133.

Guernet, C. and Robert, P., 1973. Sur l' existence de bauxites d' age jurassique en Eubée (Gréce), CR Acad. Sci. Paris, 276, 885-887.

Katsikatsos, G., 1976. La structure tectonique d'Attique et de I'ile d'Eubée, Bull Soc Géol Fr, 19, 211-228.

Katsikatsos, G., Kounis, G., Fytikas, M., Mettos, A. and Vidakis, M., 1980. Geological map of Greece, Limni Sheet 1:50,000, IGME Publ. Dept., Athens.

Katsikatsos, G., Kounis, G. and Fytikas, M., 1981. Geological map of Greece, Psachna-Pilion sheet 1:50,000, IGME Publ. Dept., Athens.

Katsikatsos, G., Mettos, A. and Vidakis, M., 1984. Geological map of Greece, Istiea Sheet 1:50,000, IGME Publ. Dept., Athens.

Kukoc, D., Gorican, S.,'Košir, A., Belak, M., Halamic, J. and Hrvatovic, H., 2015. Middle Jurassic age of basalts and the post-obduction sedimentary sequence in the Guevgueli Ophiolite Complex (Republic of Macedonia), Int. J. Earth Sci. (Geol. Rundsch.), 104, 435-447.

Machairas, G., 1978. Geological Map of Greece, Larymna Sheet 1:50,000 Inst Geo Mining Res., IGME Publ. Dept., Athens.

Meléndez, G., 1989. El Oxfordiense en el sector central de la Cordillera Ibérica (provincias deZaragoza y Teruel), Institución Fernando el Católico-Instituto de Estudios Turolenses, Zaragoza-Teruel.

Meléndez, G. and Martínez Cotanda, S., 2007. Stratigraphic gaps and evidence for subaerial exposure at the Middle-Upper Jurassic boundary in the south of Zaragoza (Ricla-Aguilón area; Aragonese branch of the Iberian range, NE Spain), Actas del III Encuentro de Jóvenes 
Investigadores en Paleontología. In: Almécija, S., Casanovas-Vilar, I., Furió, M., Maduren, J., Marmi, J. and Vila, B., eds., 117-134.

Robertson, A.H.F., Trivić, B., Đerić, N. and Bucur, II., 2013. Tectonic development of the Vardar ocean and its margins: evidence from the Republic of Macedonia and Greek Macedonia, Tectonophysics, 595-596, 25-54.

Scherreiks, R., 2000. Platform margin and oceanic sedimentation in a divergent and convergent plate setting (Jurassic, Pelagonian Zone, NE Evvoia, Greece), Int. J. Earth Sci., 89, 90-107.

Scherreiks, R., Bosence, D., BouDagher-Fadel, M., Meléndez, G. and Baumgartner, P.O., 2010. Evolution of the Pelagonian carbonate platform complex and the adjacent oceanic realm in response to plate tectonic forcing (Late Triassic and Jurassic), Evvoia, Greece, Int. J. Earth Sci., 99, 1317-1334.

Scherreiks, R., Meléndez, G., BouDagher-Fadel, M., Fermeli, G. and Bosence, D., 2014 Stratigraphy and tectonics of a time-transgressive ophiolite obduction onto the eastern margin of the Pelagonian platform from Late Bathonian until Valanginian time, exemplified in northern Evvoia, Greece, Int. J. Earth Sci., 103, 2191-2216.

Spray, J.G. and Roddick, J.C., 1980. Petrology and Ar geochemistry of some Hellenic subophiolite metamorphic rocks, Contrib. Mineral Petrol., 72, 43-55. 